\title{
Impact of Foliar Application of Urea on Fruit Set, Return Bloom and Growth of Apple cv. Red Delicious
}

\author{
Mohd Zubair $^{1 *}$, F.A. Banday ${ }^{2}$,Jahangeer A. Baba', M.U. Rehman², \\ S.S. Hussain ${ }^{1}$ and Umar I. Waida ${ }^{2}$ \\ ${ }^{1}$ KrishiVigyan Kendra/Extension Training Centre SKUAST-Kashmir, \\ Malangpora (Pulwama) J\&K, 192301, India \\ ${ }^{2}$ Division of Fruit Science, SKUAST-K, Malangpora (Pulwama) J\&K, 192301, India \\ *Corresponding author
}

\begin{tabular}{|c|c|}
\hline & A B S T R A C T \\
\hline & \multirow{5}{*}{$\begin{array}{l}\text { The present study was carried out in the Division of Fruit Science, SKUAST- } \\
\text { Kashmir, Shalimar, Srinagar during the year } 2013 \text { and } 2014 \text {. Twenty five year } \\
\text { old apple trees of cv. Red Delicious were selected at the Sher-e-Kashmir } \\
\text { university of Agricultural Sciences and Technology, Shalimar, Kashmir. Urea } \\
(0.3 \text { and } 0.5 \%) \text { were sprayed } 4 \text { weeks after petal fall and urea }(0.3,1,2 \text { and } 5 \\
\%) \text { were sprayed after harvest. Results revealed that post-harvest urea sprays } \\
\text { @ } 2 \% \text { and } 5 \% \text { at } 10 \% \text { leaf fall were found best to increase fruit set and yield. } \\
\text { Post-harvest urea spray ( } 2-5 \%) \text { established supremacy to increase return } \\
\text { bloom. Different levels of urea at different timings were non-significant with } \\
\text { respective to tree height. However, } 5 \text { per cent urea applied at } 10 \text { per cent leaf } \\
\text { fall resulted in maximum tree volume and followed by } 2 \text { per cent urea applied } \\
\text { at } 10 \text { per cent leaf fall. All the treatments differed significantly with respect to } \\
\text { fruit girth and shoot growth. }\end{array}$} \\
\hline $\begin{array}{l}\text { Apple, } \\
\text { Growth, Urea, } \\
\text { Return bloom. }\end{array}$ & \\
\hline Article Info & \\
\hline $\begin{array}{l}\text { Accepted: } \\
\text { 21 June } 2017 \\
\text { Available Online: } \\
\text { 10 July } 2017\end{array}$ & \\
\hline & \\
\hline
\end{tabular}

\section{Introduction}

In India, amongst the temperate fruits, apple accounts for the highest production. Its average productivity is $26 \mathrm{t} / \mathrm{ha}$ in USA in comparison to $5.8 \mathrm{t} / \mathrm{ha}$ in India (Kishore et al., 2006). It accounts for about 10 per cent of the total fruit production of the country. This is indicative of a great scope available for us to improve the productivity and production of apple in Kashmir. Red Delicious is one of the most famous and most widely grown apple variety in Kashmir as well as in world. Apple tree, like other plants, need different nutrients in varying quantities to achieve proper growth and fruiting. The decreasing trend in apple productivity during the last decade due to changing climate scenario has caused a serious concern to the fruit growers and planners of the country. Several factors like inadequate pollinizer proportion, reduction in natural population of pollinating agents, occurrence of spring frosts, hails and gales, nutrient deficiencies, droughts etc. are the factors leading to poor fruit setting in Delicious apple (Gautam et al., 2004). Heavy 
crops during the previous year can reduce flower formation for the next year by reducing growth or preventing flower formation. Perennial fruit crops initiate flower buds for next season's crop in the current season, and for most deciduous fruit species, the alternation of large and small crops is caused by competition between the current season's crop and the coming season's flower buds.

Excessive crop in the on year depletes the nutrients needed to form new fruit buds; however there is also evidence that seedproducing hormones exported from the developing ovules have a direct inhibitory effect on flower development. Application of $\mathrm{N}$ in the form of urea tends to increase tree $\mathrm{N}$ storage and regulate $\mathrm{N}$ distribution, results in healthy spurs and better flowering. Nitrogen is the most important element for plant growth and development. Consequently, application of $\mathrm{N}$ fertilizers had the most significant effect in increasing crop production (Mengal and Krikby, 1987). Because of its importance in crop production, $\mathrm{N}$ fertilizer is often used as an insurance policy' to achieve maximum productivity (Sanchez et al., 1995). Application of $\mathrm{N}$ to the soil is the traditional method to supply $\mathrm{N}$ to plants.

While it effectively improves plant growth, soil $\mathrm{N}$ application usually improves plant growth, soil $\mathrm{N}$ application usually has a low recovery and high risk of losses to leaching (Dines et al., 2002). Several researchers have shown that applications of $\mathrm{N}$ to foliage (foliar $\mathrm{N}$ applications) have a higher recovery rate than soil applications (Rosecrance et al., 1998). Applying urea in spring and/ or autumn to apple trees as a substitute or supplement to soil $\mathrm{N}$ dressing has been reported to increase the amount of shoot growth (Shim et al., 1972). However, when N status of experimental trees was high, growth responses to urea sprays were not obtained. Thus for increasing the apple production and productivity, it seems to be desirable to have some of technological intervention in the package of practice for apple growers so that we can be able to boost up the productivity and encourage the farmer to grow and earn more.

\section{Materials and Methods}

The experiment was conducted on twenty five years old trees of uniform size and vigor. The uniform cultural practices as per the package of practices of SKUAST-Kashmir were given to experimental trees.

The Kashmir represents the climatic conditions prevailing in the temperate zone of the Jammu and Kashmir state. The Jammu and Kashmir state is situated at $32^{\circ} .17^{\prime}$ to $37^{\circ} .05^{\prime} \mathrm{N}$ latitude and from $72^{\circ} .40^{\prime}$ to $80^{\circ} .30$ $\mathrm{E}$ longitude. The altitude of Kashmir valley varies form 1500-2000 meters above mean sea level. The maximum and minimum temperature of valley during the crop season ranged between $23{ }^{\circ} \mathrm{C}$ and $29.9{ }^{\circ} \mathrm{C}$ and $-5.8{ }^{\circ} \mathrm{C}$ to $12{ }^{\circ} \mathrm{C}$, respectively with relative humidity of 43.90 per cent and $650-800 \mathrm{~mm}$ rainfall mostly which was received from December to April.

The various treatments of urea were applied during pre and post-harvest of apple to see the effect on growth, fruit set and return bloom of apple (Table 1).

\section{Design of experiment: Randomised Block Design}

\section{Observations recorded}

Tree height $(\mathrm{m})$, Tree spread $(\mathrm{m})$, Tree volume $\left(\mathrm{m}^{3}\right)$, Tree cross sectional area $\left(\mathrm{cm}^{2}\right)$, Trunk girth $(\mathrm{cm})$, Shoot extension growth $(\mathrm{cm})$, Bloom (flower) index (\%), Fruit set 
$(\%)$, Return bloom (\%),Fruit drop (\%),Fruit retention (\%) and Fruit yield(kg/tree).

\section{Results and Discussion}

\section{Effect of pre and post-harvest urea on floral and yield characteristics}

Flowering and yield were affected by the urea application as per the figure 1 and tables 3-5. Present study revealed that fruit set $(\%)$ and fruit yield was increased by fall applications of urea, which registered fruit set $(68.59 \%)$ and yield $(88.50 \mathrm{~kg} /$ tree $)$. Pre and post-harvest urea applications had a significant effect on bloom (flower) index. Bloom (flower) index was increased by 2 and 5 per cent urea applied at 10 per cent leaf fall and minimum was recorded in control. Urea applications were significant as far as return bloom was concerned. Maximum return bloom was recorded with 5 per cent urea applied at 10 per cent leaf fall. Maximum fruit set was recorded in apple trees under 5 per cent urea applied at 10 per cent leaf fall followed by 2 per cent urea applied at 10 per cent leaf fall and minimum with 0.3 per cent urea applied 4 weeks after harvest. The fruit drop was effectively decreased by urea applications. The lowest values of fruit drop were observed with 5 and 2 per cent urea applied at 10 per cent leaf fall. The trees under control recorded maximum fruit drop. Highest fruits were retained with urea 5 per cent applied at 10 per cent leaf fall followed by 2 per cent urea applied at 10 per cent leaf fall and maximum fruit yield was obtained in apple trees treated with 0.5 per cent urea applied after 4 weeks of petal fall.

Nitrogen has both direct and indirect effects of flowering. Leaves can absorb inorganic and organic nitrogen sources. Small pores within leaf cuticles can take up urea, ammonium and nitrate.
These pores are lined with negative molecules. Therefore uptake of cations (such as ammonium) is faster than anions (such as nitrates). Uptake of small, uncharged molecules like urea is fast. Urea is commonly used for foliar fertilization because of its uncharged, high solubility and it is rapidly and efficiently absorbed by leaves.

Oland (1963) reported significantly yield increases in both "on" and "off" years of 'Gravestien' trees growing in sod that had received post-harvest sprays of urea. In this study urea sprays increased the $\mathrm{N}$ content of spur buds as measured from November to February. Leaf $\mathrm{N}$ content of trees receiving no nitrogen or soil applications of calcium nitrate was below 2 per cent.

Williams (1965) found that leaf $\mathrm{N}$ was positively correlated with the per cent floral buds and with fruit yield in the second year of applications of urea to 10 year old 'Starkspur Golden' Delicious' trees. In the first year fruit set was increased 11 per cent with the urea treatment. Floral bud imitation during second year of treatment was increased by 7 per cent in both years.

Fallahi (1997) observed lower yields of 'Redspur Delicious' from trees that had received low annual $\mathrm{N}$ (45.3 g/tree) applications but no significant difference in yields among trees that received $\mathrm{N}$ at 181.4 to $589.6 \mathrm{~g} /$ tree. Fruit $\mathrm{N}$ concentration tended to increase with increasing rate of $\mathrm{N}$ application.

Return bloom of 75.3 per cent was observed with 5 per cent urea applied at 10 per cent leaf fall in present study. This is because leaves rapidly absorb a majority of the urea form foliar spray applications in fall, even during leaf senescence and translocate the absorbed $\mathrm{N}$ from the leaves into storage tissues. The results are similar to those of Dong et al., (2002) and Rosecrace et al., (1998). With 
woody perennial plants, fall sprays with urea can increase the level of storage $\mathrm{N}$ compounds such as amino-acids and proteins (Dong et al., 2002). The amount of foliar absorbed $\mathrm{N}$ subsequently exported to other parts of woody plants may differ according to the physiological state of growth. During senescence, 23-70 per cent of initial apple leaf $\mathrm{N}$ is reabsorbed by the tree (Shim et al.,
1972). Using ${ }^{15} \mathrm{~N}$ techniques, Hill-cottingham and Lloyd Jonnes (1975) found that about 62 per cent of leaf fall absorbed $\mathrm{N}$ from autumn applications of urea to apple trees was recovered in permanent tissues during dormancy and that this $\mathrm{N}$ was evenly distributed among root and stem tissues of the stock scion.

Fig.1 Effect of pre and post-harvest urea on floral characteristics

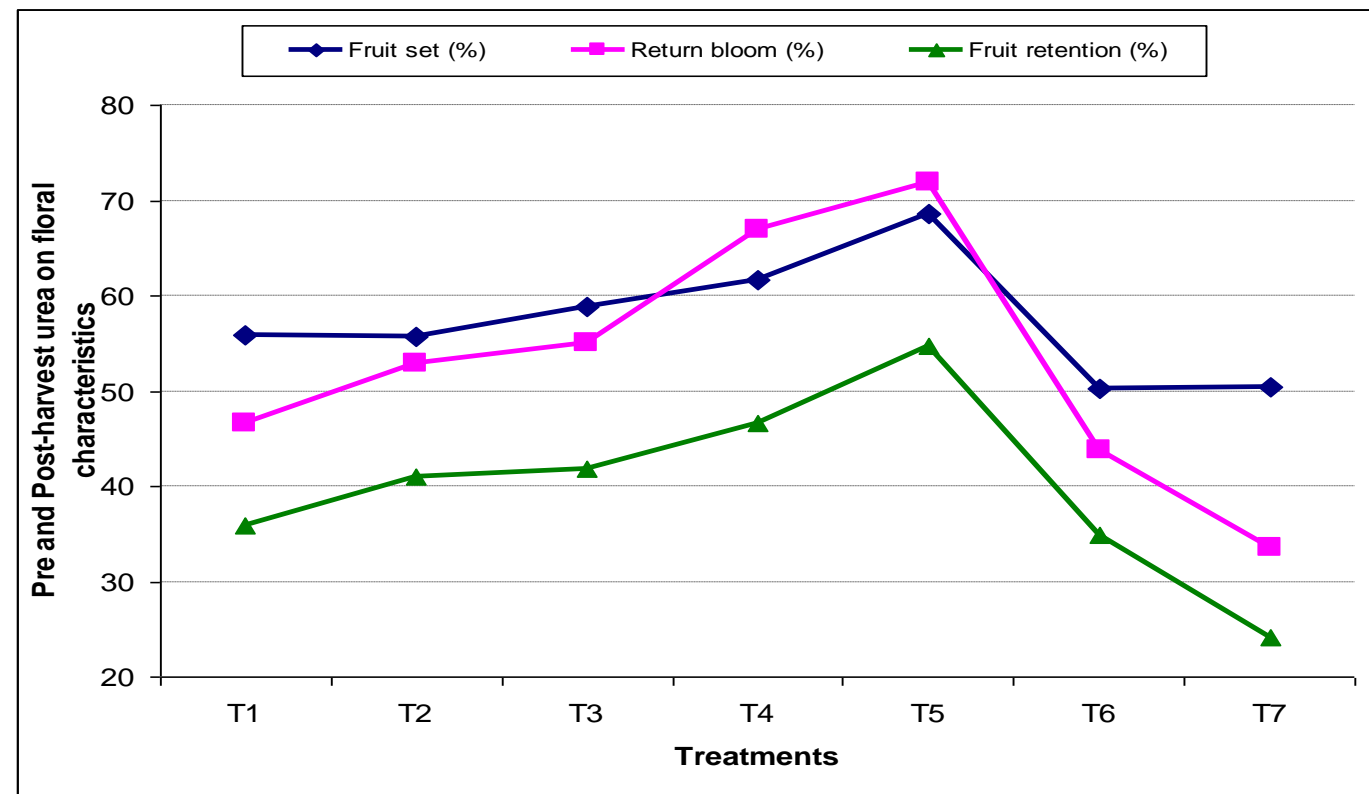

$\mathrm{T}_{1}=$ Urea $0.3 \%$ (4 weeks after petal fall)

$\mathrm{T}_{2}=$ Urea $0.5 \%$ (4 weeks after petal fall)

$\mathrm{T}_{3}=$ Urea $1 \%$ (Immediately after harvest)

$\mathrm{T}_{4}=$ Urea $2 \%(10 \%$ leaf fall $)$

$\mathrm{T}_{5}=$ Urea $5 \%(10 \%$ leaf fall $)$

$\mathrm{T}_{6}=$ Urea $0.3 \%$ (4 weeks after harvest)

$\mathrm{T}_{7}=$ Control

Table.1 List of treatments applied during the study

\begin{tabular}{cccl}
\hline Treatment & Common name & Concentration & Time of spray \\
\hline $\mathrm{T}_{1}$ & Urea & 0.3 per cent & 4 weeks after petal fall \\
$\mathrm{T}_{2}$ & Urea & 0.5 per cent & 4 weeks after petal fall \\
$\mathrm{T}_{3}$ & Urea & 1.0 per cent & Immediately after harvest \\
$\mathrm{T}_{4}$ & Urea & 2.0 per cent & Pre-leaf fall (10 per cent leaf fall) \\
$\mathrm{T}_{5}$ & Urea & 5.0 per cent & Pre-leaf fall (10 per cent leaf fall) \\
$\mathrm{T}_{6}$ & Urea & 0.3 per cent & 4 weeks after harvest \\
$\mathrm{T}_{7}$ & Water & Control & \\
\hline
\end{tabular}


Table.2 Effect of pre and post-harvest urea sprays on tree height, spread and volume of apple cv. "Red Delicious"

\begin{tabular}{|c|c|c|c|c|c|c|c|c|c|c|}
\hline & \multirow{2}{*}{ Treatment } & \multicolumn{3}{|c|}{ Tree height (m) } & \multicolumn{3}{|c|}{ Tree spread $(\mathbf{m})$} & \multicolumn{3}{|c|}{ Tree volume $\left(\mathrm{m}^{3}\right)$} \\
\hline & & 2013 & 2014 & Pooled & 2013 & 2014 & Pooled & 2013 & 2014 & Pooled \\
\hline $\mathrm{T}_{1}$ & Urea $0.3 \%$ ( 4 weeks after petal fall) & 3.24 & 3.50 & 3.37 & 1.65 & 1.67 & 1.66 & 16.28 & 16.32 & 16.30 \\
\hline $\mathrm{T}_{2}$ & Urea $0.5 \%$ ( 4 weeks after petal fall) & 4.00 & 4.50 & 4.25 & 1.65 & 1.67 & 1.66 & 16.35 & 16.00 & 16.18 \\
\hline $\mathrm{T}_{3}$ & Urea $1 \%$ (Immediately after harvest) & 3.50 & 4.00 & 3.75 & 1.77 & 1.80 & 1.79 & 17.99 & 19.19 & 18.59 \\
\hline $\mathrm{T}_{4}$ & Urea $2 \%(10 \%$ leaf fall $)$ & 3.90 & 4.50 & 4.20 & 1.86 & 1.90 & 1.88 & 20.21 & 22.80 & 21.51 \\
\hline $\mathrm{T}_{5}$ & Urea $5 \%$ (10\% leaf fall) & 3.80 & 4.10 & 3.95 & 2.93 & 3.04 & 2.99 & 20.21 & 21.77 & 20.99 \\
\hline $\mathrm{T}_{6}$ & Urea $0.3 \%$ (4 weeks after harvest) & 3.95 & 4.02 & 3.99 & 1.49 & 1.53 & 1.51 & 15.13 & 16.70 & 15.92 \\
\hline $\mathrm{T}_{7}$ & Control & 3.00 & 3.23 & 3.12 & 1.38 & 1.40 & 1.39 & 14.25 & 15.39 & 14.82 \\
\hline & C.D $(p \leq 0.05)$ & NS & NS & NS & NS & 0.92 & 0.77 & 0.92 & 0.92 & 0.63 \\
\hline
\end{tabular}

Table.3 Effect of pre and post-harvest urea sprays on tree cross-sectional area, trunk girth and Shoot extension of apple cv. "Red Delicious"

\begin{tabular}{|c|c|c|c|c|c|c|c|c|c|c|}
\hline \multirow{2}{*}{\multicolumn{2}{|c|}{ Treatment }} & \multicolumn{3}{|c|}{$\begin{array}{c}\text { Tree cross-sectional area } \\
\left(\mathbf{c m}^{2}\right)\end{array}$} & \multicolumn{3}{|c|}{ Trunk girth $(\mathbf{c m})$} & \multicolumn{3}{|c|}{$\begin{array}{l}\text { Shoot extension growth } \\
(\mathrm{cm})\end{array}$} \\
\hline & & 2013 & 2014 & Pooled & 2013 & 2014 & Pooled & 2013 & 2014 & Pooled \\
\hline $\mathrm{T}_{1}$ & Urea $0.3 \%$ (4 weeks after petal fall) & 13.81 & 13.98 & 13.90 & 74.90 & 75.00 & 74.45 & 50.22 & 52.63 & 51.45 \\
\hline $\mathrm{T}_{2}$ & Urea $0.5 \%$ (4 weeks after petal fall) & 13.84 & 14.14 & 13.99 & 74.10 & 76.00 & 75.05 & 45.36 & 48.87 & 47.12 \\
\hline $\mathrm{T}_{3}$ & Urea $1 \%$ (Immediately after harvest) & 13.92 & 14.78 & 14.35 & 72.60 & 74.00 & 73.30 & 49.28 & 52.15 & 50.72 \\
\hline $\mathrm{T}_{4}$ & Urea $2 \%(10 \%$ leaf fall $)$ & 14.09 & 14.82 & 14.46 & 73.90 & 75.00 & 74.45 & 47.49 & 55.41 & 51.45 \\
\hline $\mathrm{T}_{5}$ & Urea $5 \%$ (10\% leaf fall $)$ & 14.00 & 15.26 & 14.63 & 75.70 & 78.25 & 76.98 & 50.81 & 60.16 & 55.49 \\
\hline $\mathrm{T}_{6}$ & Urea $0.3 \%$ (4 weeks after harvest) & 13.95 & 14.14 & 14.05 & 73.10 & 75.04 & 74.07 & 46.65 & 50.78 & 48.72 \\
\hline $\mathrm{T}_{7}$ & Control & 13.74 & 13.79 & 13.77 & 73.50 & 73.73 & 73.62 & 45.10 & 46.00 & 45.55 \\
\hline & C.D $(p \leq 0.05)$ & NS & 0.004 & $\mathbf{0 . 5 7}$ & 1.18 & 1.18 & $\mathbf{0 . 8 1}$ & 0.92 & 1.18 & 0.72 \\
\hline
\end{tabular}


Table.4 Effect of pre and post-harvest of urea sprays on petal fall, bloom length and fruit set and Return bloom of apple cv. "Red Delicious"

\begin{tabular}{|c|c|c|c|c|c|c|c|c|c|c|}
\hline & \multirow{2}{*}{ Treatment } & \multicolumn{3}{|c|}{ Bloom (Flower) index (\%) } & \multicolumn{3}{|c|}{ Fruit set (\%) } & \multicolumn{3}{|c|}{ Return bloom (\%) } \\
\hline & & 2013 & 2014 & Pooled & 2013 & 2014 & Pooled & 2013 & 2014 & Pooled \\
\hline $\mathrm{T}_{1}$ & $\begin{array}{l}\text { Urea } 0.3 \% \text { (4 weeks after petal } \\
\text { fall) }\end{array}$ & 30.45 & 36.64 & 33.55 & 53.65 & 58.15 & 55.90 & 45.23 & 48.10 & 46.67 \\
\hline $\mathrm{T}_{2}$ & $\begin{array}{l}\text { Urea } 0.5 \% \text { (4 weeks after petal } \\
\text { fall) }\end{array}$ & 26.93 & 41.69 & 34.31 & 51.45 & 60.03 & 55.74 & 51.40 & 54.30 & 52.85 \\
\hline $\mathrm{T}_{3}$ & $\begin{array}{l}\text { Urea } 1 \% \quad \text { (Immediately after } \\
\text { harvest) }\end{array}$ & 30.25 & 41.19 & 35.72 & 56.35 & 61.38 & 58.87 & 53.00 & 57.00 & 55.00 \\
\hline $\mathrm{T}_{4}$ & Urea $2 \%$ (10\% leaf fall $)$ & 32.92 & 45.64 & 39.28 & 52.35 & 70.80 & 61.58 & 66.00 & 68.00 & 67.00 \\
\hline $\mathrm{T}_{5}$ & Urea $5 \%$ (10\% leaf fall $)$ & 32.48 & 46.65 & 39.57 & 57.20 & 79.98 & 68.59 & 70.20 & 73.50 & 71.85 \\
\hline $\mathrm{T}_{6}$ & Urea $0.3 \%$ ( 4 weeks after harvest) & 24.19 & 41.38 & 32.79 & 49.08 & 55.13 & 50.22 & 42.54 & 45.00 & 43.77 \\
\hline $\mathrm{T}_{7}$ & Control & 26.40 & 34.8 & 30.60 & 45.30 & 51.88 & 50.48 & 33.00 & 34.12 & 33.56 \\
\hline & C.D $(p \leq 0.05)$ & 0.92 & 1.18 & 0.72 & 0.02 & 0.92 & 0.44 & 1.18 & 1.00 & $\mathbf{0 . 5 7}$ \\
\hline
\end{tabular}

Table.5 Effect of pre and post-harvest of urea sprays on fruit drop, retention and yield of apple cv. "Red Delicious"

\begin{tabular}{|c|c|c|c|c|c|c|c|c|c|c|}
\hline & \multirow{2}{*}{ Treatment } & \multicolumn{3}{|c|}{ Fruit drop (\%) } & \multicolumn{3}{|c|}{ Fruit retention (\%) } & \multicolumn{3}{|c|}{ Fruit yield (kg/tree) } \\
\hline & & 2013 & 2014 & Pooled & 2013 & 2014 & Pooled & 2013 & 2014 & Pooled \\
\hline $\mathrm{T}_{1}$ & Urea $0.3 \%$ ( 4 weeks after petal fall) & 23.44 & 16.48 & 19.96 & 30.21 & 41.67 & 35.94 & 80.60 & 86.60 & 83.60 \\
\hline $\mathrm{T}_{2}$ & Urea $0.5 \%$ (4 weeks after petal fall) & 19.28 & 16.43 & 17.86 & 37.07 & 44.95 & 41.01 & 85.00 & 92.00 & 88.50 \\
\hline $\mathrm{T}_{3}$ & Urea $1 \%$ (Immediately after harvest) & 16.12 & 13.65 & 14.89 & 36.64 & 46.85 & 41.75 & 79.75 & 84.23 & 81.99 \\
\hline $\mathrm{T}_{4}$ & Urea $2 \%$ (10\% leaf fall $)$ & 14.81 & 13.18 & 13.99 & 36.23 & 57.15 & 46.69 & 69.00 & 74.00 & 71.50 \\
\hline $\mathrm{T}_{5}$ & Urea $5 \%(10 \%$ leaf fall $)$ & 14.86 & 12.80 & 13.83 & 42.34 & 67.18 & 54.76 & 65.50 & 68.50 & 67.00 \\
\hline $\mathrm{T}_{6}$ & Urea $0.3 \%$ ( 4 weeks after harvest) & 16.80 & 13.85 & 15.33 & 28.50 & 41.28 & 34.89 & 61.34 & 67.34 & 64.34 \\
\hline $\mathrm{T}_{7}$ & Control & 26.70 & 26.00 & 26.35 & 22.38 & 25.88 & 24.13 & 55.15 & 60.60 & 57.88 \\
\hline & C.D $(p \leq 0.05)$ & 1.18 & 1.30 & 0.85 & 1.18 & 0.04 & $\mathbf{0 . 5 7}$ & 1.18 & 0.0004 & $\mathbf{0 . 5 7}$ \\
\hline
\end{tabular}


Cheng et al., (2002) reported 80-90 per cent of with drawl into storage in young apple nursery trees, depending on tree $\mathrm{N}$ status (more $\mathrm{N}$ was mobilized for the leaves). In peach and nectarine, trees about 50-60 per cent with drawl of urea $\mathrm{N}$ was reported (Tagliavini et al., 1998). The efficiency of leaf $\mathrm{N}$ is affected by weather conditions in the autumn (Oland, 1963).

Flowering was not affected by urea applications but initial bloom and full bloom was earlier in consecutive year because temperature was high during flowering. Neto et al., (2008) concluded that nitrogen uptake was minimum at bud break and peaked in June/July remaining more or less constant until leaf fall.

About 25 per cent of the fertilizer $\mathrm{N}$ taken up by 3 years old trees in the previous year was found in new tissues formed (flowers, leaves and 1 year old shoots) reaching 27 per cent when fine roots were also included. In these trees, 32 per cent and 54 per cent of the ${ }^{15} \mathrm{~N}$ stored in the previous year in the trunk and older shoots respectively were mobilized to the new growth in the flowering year.

\section{Effect of pre and post- harvest urea on growth characteristics}

The data presented in tables 1 and 2 shows that the growth characters of apple were greatly influenced by post-harvest applications of foliar urea spray (2 and $5 \%$ ) at 10 per cent leaf fall).

Maximum tree spread $(2.99 \mathrm{~cm})$, tree volume $\left(21.51 \mathrm{~m}^{3}\right)$, tree cross sectional area (14.63 and $\left.14.46 \mathrm{~cm}^{2}\right)$, trunk girth $(76.98 \mathrm{~cm})$ and shoot extension growth $(55.49 \mathrm{~cm})$ was increased by 2 and 5 per cent urea applied at 10 per cent leaf fall). This may be attributed to the fact that nitrogen plays an active role in cell division and cell elongation, thus helps in development. The another possible reason for the increased growth with the increasing levels of nitrogen might be higher availability of $\mathrm{N}$ content in soil and higher $\mathrm{N}$ content in various parts of apple.

However, the method of $\mathrm{N}$ application during the summer affected the amount of ${ }^{15} \mathrm{~N}$ uptake of nitrogen by trees in autumn. Trees that received foliar $\mathrm{N}$ applications in the summer recorded higher $\mathrm{N}$ uptake in the autumn than trees that soil received $\mathrm{N}$ applications or in controls. Trees that received either soil or foliar $\mathrm{N}$ applications in the summer took more $\mathrm{N}$ applications in the autumn. In contrast, trees that received soil $\mathrm{N}$ applications during the summer took up more $\mathrm{N}$ from foliar application in the autumn than soil $\mathrm{N}$ application in the autumn. Summer foliar N applications promoted root growth and significantly increased feeder root initiation which has higher ability of nutrient absorption (Dong et al., 1999). Although trees receiving soil $\mathrm{N}$ application during the summer developed more above ground part and less roots, while trees receiving soil $\mathrm{N}$ applications during the summer appear to benefit more from foliar $\mathrm{N}$ uptake in the autumn.

The similar findings were reported by Dong et $a l$. , (2005). It has been reported that the late season foliar urea applications improves growth, $\mathrm{N}$ reserves promoting growth and fruiting in the following season (Rosecrance et al., 1998; Sanchez et al., 1990).

While going through the results, it is revealed that that all the post-harvest nitrogen applications led to significant increase in growth characteristics of apple. Post-harvest urea applications after harvest appear to be most efficient in producing $\mathrm{N}$ to the developing flower buds. Therefore, apple leaves absorbed considerable fraction of the foliar applied nitrogen between September and November to increase the return bloom. 


\section{References}

Cheng, L., Dong, S. and Fuchigami, L.H. 2002. Urea uptake and mobilization by apple leaves in relation to tree nitrogen status in autumn. J. Hortic. Sci Biotech., 77: 13-18.

Dines, D., Karlen, D.L., Jaynes, D.B., Kasper, T.K, Hatfield, J.L., Calvin, T.S. and Cmbardella, C.A. 2002. Nitrogen management strategies to reduce nitrate leaching in tile drained mid -western soils. Agronomy J., 94: 153-171.

Dong, S., Cheng, L. and Fuchigami, L.H. 1999. Ammonium ion uptake by feeder and extension roots of MM-106 apple rootstock. HortSci, 34: 492.

Dong, S., Cheng, L., Scagel, C. and Fuchigami, L.H. 2005. Nitrogen absorption and distribution from urea applied in autumn to leaves of young potted apple (Malus domestica) trees. Tree Physio, 22:13051310.

Dong, S., Cheng, L., Scagel, C.F. and Fuchigami, L.H. 2002. Nitrogen absorption, translocation and distribution from urea applied in autumn to leaves of young potted apple (Malus domestica) trees. Tree Physiol., 22: 1305-1310.

Fallahi, E. 1997. Pre-harvest nitrogen optimization for maximizing yield and postharvest yield and post-harvest fruit quality of apples. HortSci, 448: 415-419.

Gautam, D.R., Sharma, G. and Jindal, K.K. 2004. Fruit setting problems of apples under changing climatic scenario of north-western Himalayas of India. Acta Hort., 662: 435441.

Hill-Cottingham, D.G. and Lollyd-Jones, C.P. 1975. Nitrogen-15 in apple nutrition investigations. J. Sci. Food Agric., 26: 165173.
Kishore, D.K., Sharma, S.K. and Prananick, K.K. 2006. Temperate Horticulture. Current Scenario, pp. 193-200.

Mengel, K. and Krikby, E.A. 1987. Principles of plant nutrition International Potash Institute: Bern, Switzerland, pp. 1-50.

Neto, C., Carraca, C., Clemete, J. and Varennes, A.D. 2008. Nitrogen distribution and remobilization and re-cycling in young orchard of non-bearing "Rocha" pear trees. Scientia Hort., 118: 299-307.

Oland, K. 1963. Response of cropping apple trees to post-harvest urea sprays. Nature, 198: 1282-1283.

Rosecrance, R.C., Jhonson, R.C. and Weinbaum, S.A. 1998. The effect of timing of postharvest foliar urea sprays on nitrogen absorption and partitioning in peach and nectarine trees. J. Hortic. Sci. Biotechnol., 73: 856-861.

Sanchez, E.E., Rigetti, T.L. and Sugar, D.L.P.B. 1990. Responses of 'Comice' pear tree to a post-harvest urea spray. J. Hortic. Sci., 65: 541-546.

Sanchez, E.E., Rigetti, T.L. and Sugar, D.L.P.B. 1990. Responses of 'Comice' pear tree to a post-harvest urea spray. J. Hortic. Sci., 65: 541-546.

Shim, K.K., Titus, J.S. and Splittstoesser, W.E. 1972. The utilization of post-harvest urea sprays by senescing apple leaves. J. Amer. Soc. Hort. Sci., 97: 592-596.

Taglaivini, M., Millard, P. and Quartieri, M. 1998. Storage of foliar-absorbed nitrogen and remobilization for spring growth in young nectarine (Prunus persica var. Nectraine) trees. Tree Physiol., 18: 203-207.

Williams, R.R. 1965. The effect of summer nitrogen applications on the quality of apple bloosom. J. Hort. Sci., 40: 31-41.

\section{How to cite this article:}

Mohd Zubair, F.A. Banday, Jahangeer A. Baba, M.U. Rehman, S.S. Hussain and Umar I. Waida. 2017. Impact of Foliar Application of Urea on Fruit Set, Return Bloom and Growth of Apple cv. Red Delicious. Int.J.Curr.Microbiol.App.Sci. 6(7): 2123-2130.

doi: https://doi.org/10.20546/ijcmas.2017.607.249 